\title{
Efficient Straightforward Synthesis of Amidopiperazinophanes as Versatile Novel Supramolecular Scaffolds
}

\author{
Ayyavu Thirunarayanan*a,b (iD \\ Sivasamy Selvarania \\ Gracia Francisco $^{\text {b }}$ \\ Perumal Rajakumar*a \\ a Department of Organic Chemistry, University of Madras, \\ Guindy Campus Chennai - 600 025, India \\ thiruorgchem81@gmail.com \\ perumalrajakumar@gmail.com \\ ${ }^{b}$ Department of Chemical Engineering, Biotechnology and \\ Materials, FCFM, Universidad de Chile, Av. Beauchef 851, \\ Santiago, Chile
}
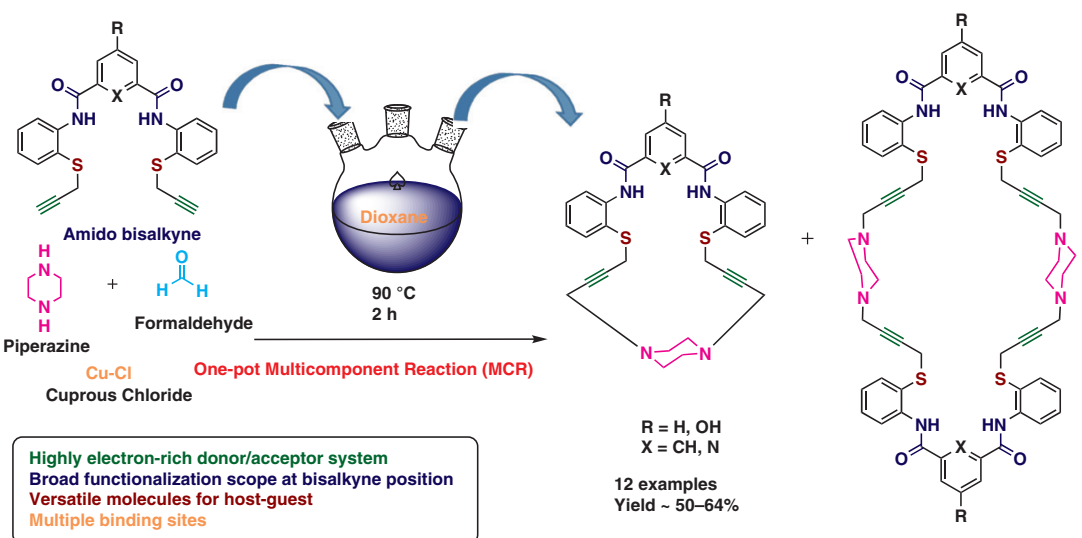

Received: 01.09.2019

Accepted after revision: 02.11.2019

Published online: 02.12 .2019

DOI: 10.1055/s-0039-1690333; Art ID: so-2019-d0019-I

License terms: (C)

(c) 2019. The Author(s). This is an open access article published by Thieme under the terms of the Creative Commons Attribution License, permitting unrestricted use, distribution and reproduction, so long as the original work is properly cited.

(https://creativecommons.org/licenses/by/4.0/)

Abstract A simple one-pot synthesis of amidopiperazinophanes with a combination of electron-deficient amide groups and electron-rich alkyne and piperazine functionalities has been achieved by using multicomponent reaction (MCR) methodology with the Mannich reaction. Herein, we demonstrate the synthesis of macrocyclic amide structures in good yields. These macrocycles, with electron donor/acceptor sites, are versatile molecules for host-guest and binding.

Key words supramolecular, piperazine, host-guest, amide, Mannich reaction, multicomponent reaction

Molecular recognition and highly responsive signaling play an important role in host and guest interactions, which have been extensively studied in biological systems via supramolecular host-guest mechanisms. ${ }^{1}$ Generally, macrocyclic structures with heterocyclic ring systems possess numerous binding sites for metal ions ${ }^{2 a}$ that provide attractive properties as molecular hosts. In the last two decades, the scaffolds of amide cyclophanes with rigid and highly sterically encumbered structures have been explored for their use in supramolecular chemistry. ${ }^{2 b-d}$ Moreover, a piperazine precursor to the macrocyclic system provides an additional donor site with the nitrogen embedded directly in the macrocyclic backbone.

Formation of macrocycles containing amide bonds can lead to a range of pharmaceutically interesting biological activities. ${ }^{3}$ Moreover, the presence of amide functionalities in supramolecular structures facilitates their use as molec- ular receptors ${ }^{4}$ for molecular recognition; ${ }^{5}$ for instance anti-HIV active macrocyclic amides. ${ }^{6}$ In addition, cyclic amides $^{7}$ have structural rigidity, receptor selectivity, and biochemical stability. Recently, functionalized aza-oxo-thia macrocycles bearing tetra amides have been employed as potential antimicrobial and anticancer agents. ${ }^{8}$ The combination of a fluorophore-tag with cyclic peptides facilitates the selective detection of $\mathrm{Hg}(\mathrm{II}) .{ }^{9}$ Furthermore, the possibility of intra- and intermolecular hydrogen bonding by the amide functionality may lead to compact conformations and functions. ${ }^{10}$ Cyclic amides have also been used as nanomaterial devices by the formation of tubular structures that lead to stacking and self assembly. ${ }^{11}$ Moreover, transitionmetal ions such as $\mathrm{Ru}(\mathrm{II}), \mathrm{Pd}(\mathrm{II}), \mathrm{Ni}(\mathrm{II}), \mathrm{Co}(\mathrm{II}), \mathrm{Cu}(\mathrm{II})$, and $\mathrm{Fe}(\mathrm{III})^{12}$ show selective metal ion complexation behavior with cyclic amides by formation of stable complexes. Conversely, cyclic amides have been found to be suitable neutral hosts for anionic guest systems. ${ }^{13}$ Earlier, we reported cyclophanes with intra-annular amide functionalities for selective ion transportation ${ }^{14}$ as well as for the development of bioactive compounds. ${ }^{15}$ Piperazine-containing cyclophanes have rarely been reported. ${ }^{16,5 c}$ The ability of piperazines to form hydrogen bonds with guests plays a pivotal role in biomedical and pharmaceutical fields. The presence of a piperazine in a cyclophane ${ }^{17}$ offers rigidity. Piperazine could act as an electron-donor group along with alkynes in cyclic amides. ${ }^{18}$ In this sense, piperazine-amide macrocycles with a number of binding sites as well as with electronrich heteroatoms such as $\mathrm{N}, \mathrm{S}$, and rigid alkynes are of potential interest. ${ }^{19}$ Several attempts have been made to synthesize amide cyclophanes containing piperazines, ${ }^{20}$ but these have involved multi-step approaches, necessitating protection and deprotection strategies, extended reaction time for cyclization, and low reaction yields. ${ }^{21}$ 
Herein, we report a simple approach for the synthesis of novel amidopiperazinophanes 1-6 and 7-12 (Figure 1) of a
1:1 and 2:2 oligomeric nature, respectively, by using propargylamine and piperazine as skeletons through one-pot
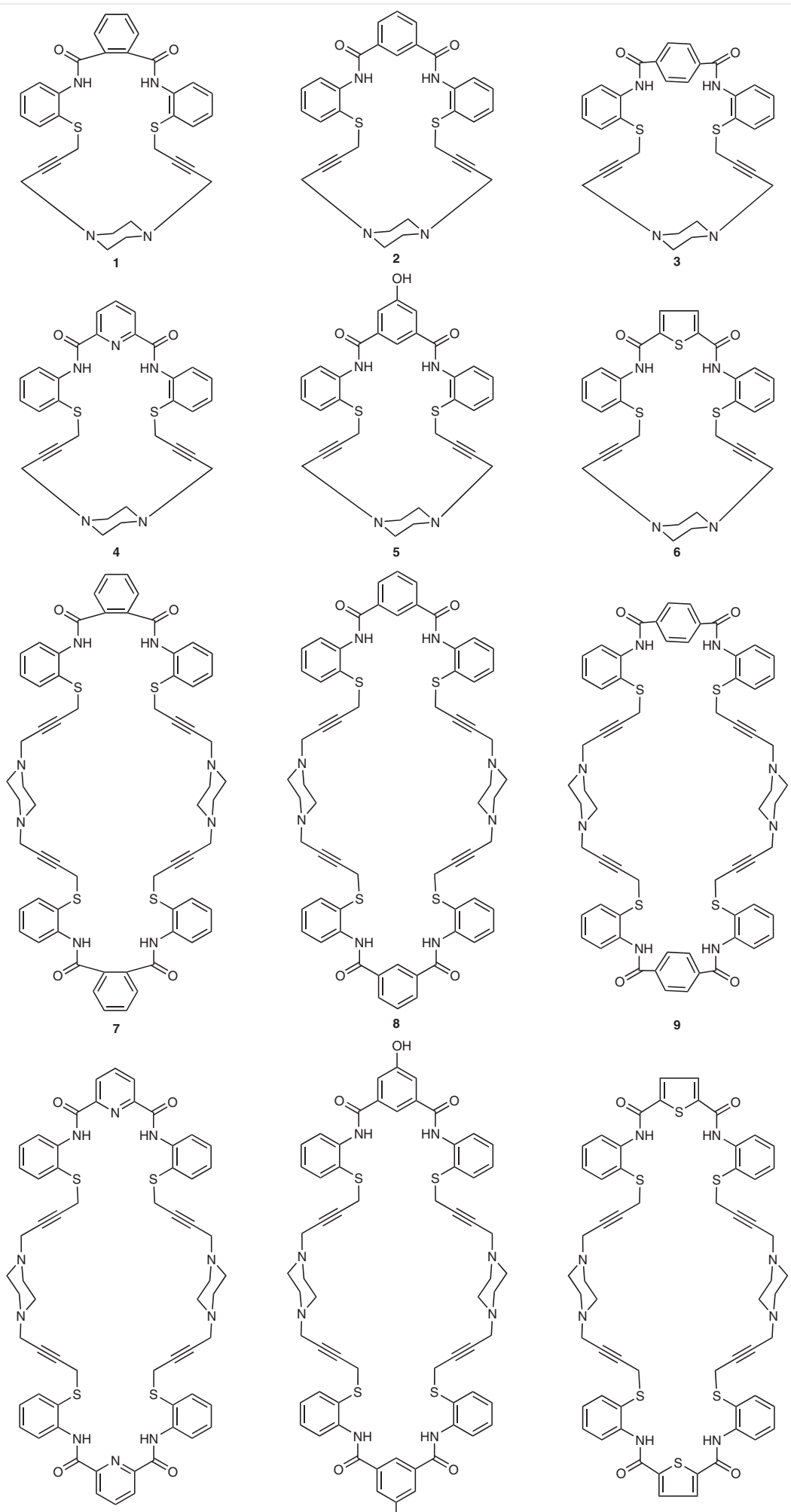

10
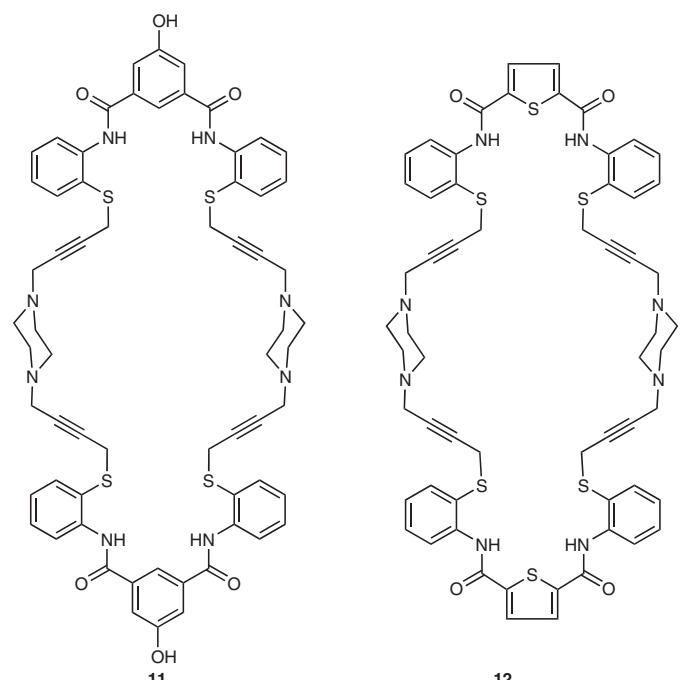

Figure 1 Structures of piperazinoamide based 1:1 and 2:2 oligomeric forms of macrocycles 1-12 
multicomponent reaction (MCR) methodology. Moreover, this synthetic approach has advantages, including ease of manipulation, simple purification and intrinsic atom economy. These 1:1 monomeric and 2:2 dimeric forms of amidopiperazinophanes offer both $\pi$ electron-rich donor $(\pi=$ phenyl, ethynyl) and efficient hydrogen-bond acceptor systems (tertiary amine). Our observations suggest that these amide cyclophanes could be potential candidates for pharmaceutical applications. Moreover, our findings open up new perspectives to design and develop supramolecular scaffolds with amide functionalities in the macrocyclic ring by using this simple synthetic approach.

Amidopiperazinophanes can be obtained from the corresponding $S$-bispropargyloxy precyclophanes. The precyclophane bis-alkyne system can be constructed from the reaction of acid chlorides and S-propargyloxy-2-aminothiophenol. Mannich reaction methodology leads to the amide macrocycles in an effective manner by condensation of the terminal bisalkyne, piperazine, and formaldehyde through a multicomponent reaction (MCR).

To achieve target amide macrocycles 1-12, precyclophanes 13-18 with terminal bisalkynes were used as the main building blocks with $S$-propargyloxy-2-aminothiophenol $\mathbf{1 9}^{3 \mathrm{~b}}$ as the other starting precursor.
In this context, our initial aim focused on the synthesis of the precyclophanes using various aromatic diacid chlorides including phthaloyl chloride $\mathbf{2 0}$, isophthaloyl chloride 21, terephthaloyl chloride 22, pyridine-2,6-dicarboxylic acid chloride 23, 5-hydroxyisophthaloyl dichloride $\mathbf{2 4}$, and thiophene-2,5-dicarbonyl dichloride 25. Reaction of 1.0 equiv of each diacid chloride with 2.1 equiv of $S$-propargyloxy-2-aminothiophenol 19 at room temperature afforded the amide precyclophanes 13, 14, and 15 in 56, 65, and 59\% yields, respectively. The synthesis was extended to incorporate hydroxyl and electron-rich heteroatoms such as $\mathrm{N}$ and $\mathrm{S}$ at the intra-annular position of the piperazinophanes, presenting features for hydrogen bonding and stacking along with binding sites for guest species. As a consequence, precyclophanes 16, 17, and 18 were prepared by treating $S$-propargyloxy-2-aminothiophenol 19 with freshly prepared pyridine-2,6-dicarbonyl dichloride 23, 5-hydroxyisophthaloyl 24, and thiophene-2,5-dicarbonyl dichloride $\mathbf{2 5}$ in the presence of triethylamine in dichloromethane at room temperature for $12 \mathrm{~h}$ to obtain 71,67 , and $78 \%$ yields, respectively (Scheme 1 ). The aromatic diacid chlorides 20-25 were synthesized according to the reported procedure. ${ }^{22}$

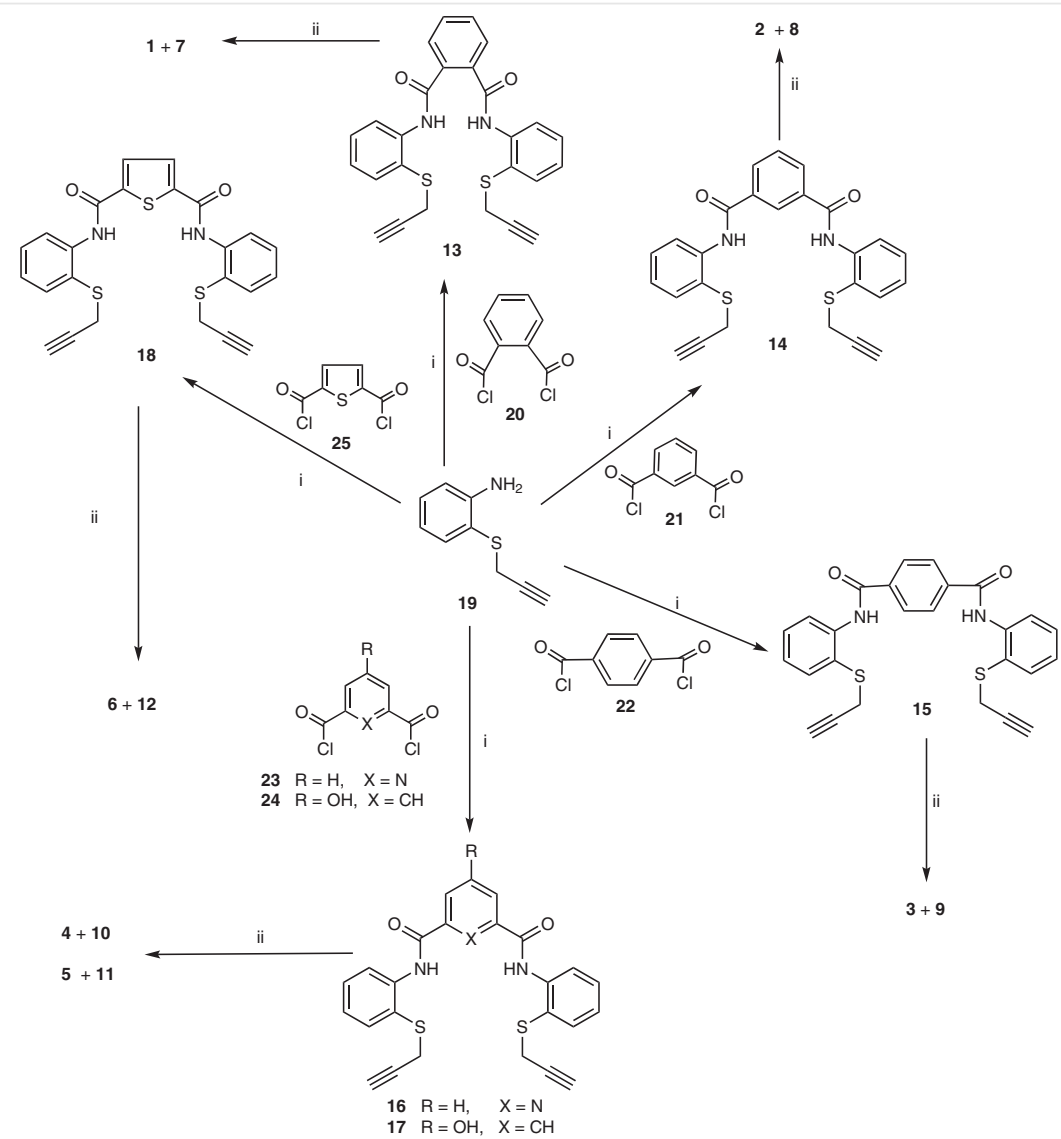

Scheme 1 Reagents and conditions: (i) $\mathrm{NEt}_{3}, \mathrm{CH}_{2} \mathrm{Cl}_{2}$ (dry), 12 h: (ii) piperazine, 37-41\% aq. formaldehyde, $\mathrm{CuCl}, 90{ }^{\circ} \mathrm{C}, 2 \mathrm{~h} .1$ (31\%); 2 (37\%); 3 (30\%); 4 (36\%); 5 (32\%); 6 (30\%); 7 (23\%); 8 (24\%); 9 (27\%); 10 (30\%); 11 (18\%); 12 (26\%); 13 (56\%);. 14 (65\%); 15 (59\%); 16 (71\%); 17 (67\%); 18 (78\%). 
The structure of precyclophane $\mathbf{1 6}$ was confirmed by ${ }^{1} \mathrm{H}$ NMR spectroscopic analysis by the appearance of longrange coupling between the two-proton triplet at $\delta=1.91$ $(t, J=2.1 \mathrm{~Hz}, 2 \mathrm{H})$ for the acetylenic proton and a doublet at $\delta=3.41(\mathrm{~d}, J=2.4 \mathrm{~Hz}, 4 \mathrm{H})$ for $S$-methylene proton. The amide $-\mathrm{NH}$ proton appeared as a singlet at $\delta=10.74$ in addition to the rest of the signals for eleven aromatic protons. In the ${ }^{13} \mathrm{C}$ NMR spectrum, compound $\mathbf{1 6}$ presented signals from alkyne carbons, $S$-methylene and $N$-methylene carbons at $\delta=24.4,72.4$, and 79.1, respectively, the amide carbonyl carbon resonated at $\delta=161.5$ and nine aromatic carbons were present. The amide carbonyl carbon of $\mathbf{1 6}$ was further evidenced by the appearance of a strong absorption band at $1656 \mathrm{~cm}^{-1}$ in the IR spectrum. Finally, the precyclophane structure 16 was confirmed by the observation of a molecular ion peak at $m / z 457\left[\mathrm{M}^{+}\right]$in the mass spectrum.

The ${ }^{1} \mathrm{H}$ NMR spectrum of precyclophane 18 contained signals at $\delta=2.21(t, J=2.7 \mathrm{~Hz}, 2 \mathrm{H})$, and $\delta=3.49(\mathrm{~d}, J=2.4$ $\mathrm{Hz}, 4 \mathrm{H}$ ) for the acetylenic and $S$-methylene units, respectively, with a sharp singlet at $\delta=9.47$ corresponding to the two amide $\mathrm{NH}$ protons, in addition to signals for ten aromatic protons. The ${ }^{13} \mathrm{C}$ NMR spectrum of precyclophane $\mathbf{1 8}$ displayed resonances at $\delta=25.3,72.8$, and 79.4 for alkyne, $\mathrm{S}-\mathrm{CH}_{2}$ and $\mathrm{N}-\mathrm{CH}_{2}$ carbons, respectively, aromatic carbon signals at $\delta=120.3-143.8$ and a resonance at $\delta=158.8$ for the amide carbonyl carbon. A molecular ion peak of precyclophane 18 was observed at $m / z 462\left[\mathrm{M}^{+}\right]$in the mass spectrum. Further spectroscopic and analytical data matched with the structure of the precyclophane $\mathbf{1 8}$.

Our aim was to extend the study to various amidopiperazines with different heteroatoms and aromatic monocyclic spacer units. Hence, coupling of 1.0 equiv of precyclophane 13-15 with 2.0 equiv of $37-41 \%$ aqueous formaldehyde, and 1.0 equiv of piperazine in the presence of a catalytic amount of $\mathrm{CuCl}$ in anhydrous dioxane at $90{ }^{\circ} \mathrm{C}$ for $2 \mathrm{~h}$ furnished functionalized 1:1 oligomeric amide cyclophanes $\mathbf{1}$, $\mathbf{2}$, and $\mathbf{3}$ with propargylamine and piperazine-containing skeletons in 31,37 , and $30 \%$, yields, respectively, and 2:2 oligomeric cyclophane amides $\mathbf{7}, \mathbf{8}$, and 9 with propargylamine and piperazine skeletons in 24,27 , and $30 \%$ yields, respectively.

The proton NMR spectrum of monomeric macrocyclic amide 2 indicated the singlets at $\delta=2.10,2.87,3.54$ for the piperazinyl, $\mathrm{S}-\mathrm{CH}_{2}$, and $\mathrm{N}-\mathrm{CH}_{2}$ protons, respectively, and the amide proton appeared as a sharp singlet at $\delta=9.97$. The rest of the signals could be attributed to the aromatic protons. The ${ }^{13} \mathrm{C}$ NMR spectrum showed four different signals for acetylene, piperazinyl and methylene carbons at $\delta=$ $26.2,47.1,51.6$ and $79.3,80.5$, respectively, and a signal at $\delta=163.9$ for the amide carbonyl, in addition to the signals due to the aromatic carbons. Finally, the structure was confirmed by the appearance of a molecular ion at $m / z 566$.

The ${ }^{1} \mathrm{H}$ NMR spectrum of 2:2 dimeric amidopiperazinophane 8 showed a sharp singlet at $\delta=2.23$ for the sixteen protons of piperazinyl units, an eight-proton singlet at $\delta=$
2.99 for $\mathrm{S}-\mathrm{CH}_{2}$ protons, a sharp singlet at $\delta=3.55$ for the $\mathrm{N}$ methylene protons, signals at $\delta=7.13$ to 8.60 for the aromatic protons along with the four amide protons observed as a sharp singlet at $\delta=9.68$. In the ${ }^{13} \mathrm{C}$ NMR spectrum, signals at $\delta=25.7,46.8,51.4,79.5,80.5$ and $120.7-140.2$ corresponded to the piperazinyl, $S$-methylene, $N$-methylene, acetylenic carbons and the aromatic carbons, respectively. The amide carbonyl carbon was observed at $\delta=164$.0. The structure of 2:2 oligomeric amidopiperazinophane $\mathbf{8}$ was confirmed by the appearance of a molecular ion at $\mathrm{m} / \mathrm{z}$ $1132\left[\mathrm{M}^{+}\right]$in the mass spectrum. Similarly, the structure of the remaining 1:1 oligomeric amide macrocycles $\mathbf{1}, \mathbf{3}$ and 2:2 oligomeric amidopiperazinophanes $\mathbf{5}, \mathbf{7}$ were confirmed by spectroscopic and analytical data.

The crystal structure of amidopiperazinophane 2 (Figure 2) showed a relatively planar bis(2-mercaptophenyl)isophthalamide fragment linked to the tertiary amine of the piperazine unit. The mercaptophenyl unit is highly strained and turned away from the ring of isophthalamide by $8.18(11)$ and $5.59(10)^{\circ}$, at the same time these two rings are horizontally turned towards each another by 9.10 $(12)^{\circ}$. Two intramolecular hydrogen bonds can be identified, generating $S(5)$ ring motifs and the structure is further stabilized by hydrogen bonds of $\mathrm{C}-\mathrm{H} \cdot \cdots \mathrm{S}$ and $\mathrm{C}-\mathrm{H} \cdots \mathrm{O}$. The oxygen atoms of the amide carbonyl linked to the isophthaloyl ring is disordered over two positions with an occupancy ratio of 0.41(6):0.59(6). ${ }^{23}$
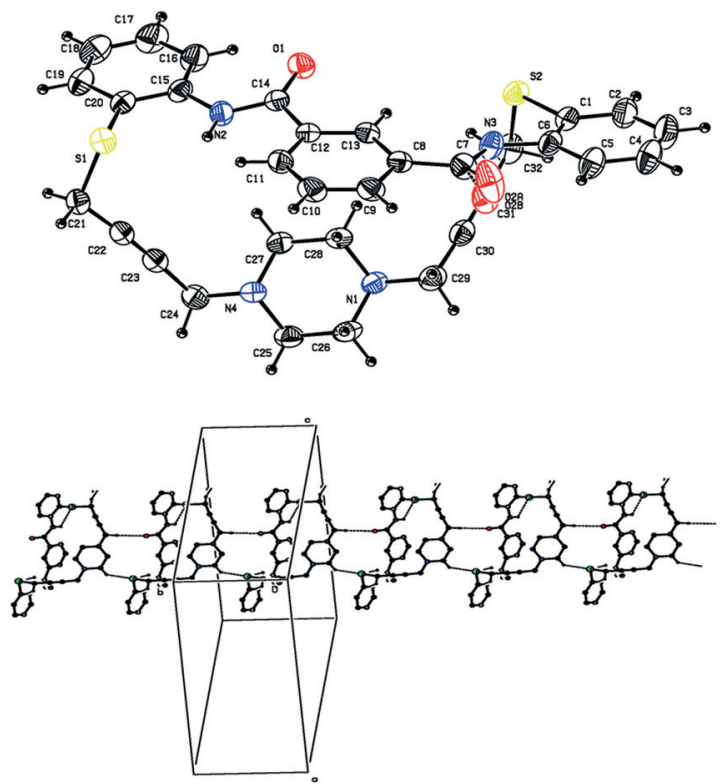

Figure 2 Single-crystal structure and molecular packing view of cyclophane amide 2

Our strategy was extended to the synthesis of amide piperazinophanes containing two and four amide groups with different functional groups, as well as electron donor/acceptor heteroatoms at intra-annular positions by 
introducing the pyridine-2,6-dicarbonyl, 5-hydroxyisophthaloyl and 2,5-thiophenedicarbonyl units. Thus, 1.0 equiv of precyclophane diynes $\mathbf{1 6}, \mathbf{1 7}$ and $\mathbf{1 8}$ were treated with $37-41 \%$ aq. formaldehyde (2.0 equiv) and piperazine (1.0 equiv), in the presence of a catalytic amount of $\mathrm{CuCl}$ in anhydrous dioxane at $90{ }^{\circ} \mathrm{C}$ for $2 \mathrm{~h}$ to form $1: 1$ oligomeric amide macrocycles $4, \mathbf{5}, \mathbf{6}$ in 36,32 , and $30 \%$ yields, respectively, and 2:2 oligomeric amides macrocycles 10, 11 and $\mathbf{1 2}$ in 23,18 , and 26 yields, respectively.

The formation of 1:1 cyclophane $\mathbf{4}$ was confirmed by the appearance of an intense absorption band at $1664 \mathrm{~cm}^{-1}$ in the FTIR spectrum for the amide carbonyl. The ${ }^{1} \mathrm{H}$ NMR spectrum displayed three sharp singlets at $\delta=2.22,3.11$, and 3.66 for the protons of the piperazinyl, $S$-methylene, and $\mathrm{N}$-methylene units, respectively, along with a sharp singlet at $\delta=10.76$ for the amide protons in the deshielded region in addition to the signals for the aromatic unit. In the ${ }^{13} \mathrm{C}$ NMR spectrum, signals for the piperazine carbons, methylene carbons connected to sulfur, and nitrogen and the amide carbon at $\delta=22.7,46.8,50.5$, and 163.1 , respectively, in addition to the aromatic carbons were observed. The molecular ion was found at $m / z 567\left[\mathrm{M}^{+}\right]$in the mass spectrum and a satisfactory elemental analysis was obtained.

Similarly, the structure of 2:2 oligomeric cyclophane amide 10 was confirmed by ${ }^{1} \mathrm{H}$ NMR spectroscopy through the appearance of a sharp singlet at $\delta=2.34$ for sixteen protons of the piperazine skeleton, an eight proton singlet at $\delta$ $=3.02$ for $S-\mathrm{CH}_{2}$ group and a singlet at $\delta=3.60$ for the $N-\mathrm{CH}_{2}$ protons with the rest of the signals at $\delta=7.20-8.54$ corresponding to the aromatic protons. The amide protons resonated at $\delta=10.71$. In the ${ }^{13} \mathrm{C}$ spectrum, signals at $\delta=24.7$, and $46.9,51.4$, and $79.3,80.5$ could be assigned to the piperazinyl, acetylenic $S-\mathrm{CH}_{2}$, and $\mathrm{N}-\mathrm{CH}_{2}$ groups, resonances between $\delta=121.9$ to 149.3 for the aromatic carbons and the amide carbons appeared at $\delta=161.5$. The FTIR spectrum showed an absorption band at $1656 \mathrm{~cm}^{-1}$ for the amide carbonyl and a molecular ion was observed at $m / z 1134$ $\left[\mathrm{M}^{+}\right]$in the mass spectrum.

Analogously, the ${ }^{1} \mathrm{H}$ NMR spectrum of the dimeric amide macrocyclic receptor 12 displayed three sharp singlets at $\delta=2.36,3.10$ and 3.56 for the piperazine, $S$-methylene and $\mathrm{N}$-methylene protons, respectively. A sharp singlet was observed at $\delta=9.53$ for the four protons of the amide unit in addition to the signals for the aromatic protons. The ${ }^{13} \mathrm{C}$ NMR spectrum displayed carbon signals at $\delta=25.7,46.8$, $51.2,79.0$, and 80.9 for the $S-\mathrm{CH}_{2}, N-\mathrm{CH}_{2}$, piperazine and alkyne carbon, respectively, in addition to signals between $\delta=120.5-143.8$ assigned to the aromatic carbons. The amide carbonyl resonance was observed at $\delta=158.8$. A molecular ion was observed at $m / z 1144\left[\mathrm{M}^{+}\right]$in the mass spectrum and its chemical composition was also evaluated by elemental analysis.
Similarly, other structures of 1:1 oligomeric and 2:2 oligomeric cyclophane amide 5, 6 and 11 bearing strong binding sites and electron-rich donor/acceptor units were completely characterized and confirmed by full spectroscopic and analytical analyses.

In summary, a simple approach to the synthesis of a family of amidopiperazinophane with an intra-annular amide unit with various spacer units has been achieved with good yields via Mannich reaction in a mild, straightforward, sequential, and rapid one-pot multicomponent reaction (MCR). ${ }^{24}$ All the amidopiperazonophane structures were completely characterized and confirmed by using standard spectroscopic and analytical methods. By taking account the merits of the synthetic strategy, our investigation will open new avenues for the design and synthesis of novel amidopiperazinophanes, with various binding sites with electron donor/acceptor units.

\section{Funding Information}

We thank UGC, New Delhi, India for financial support. A.T. thanks CSIR-UGC, New Delhi for a Senior Research Fellowship and S.S. thanks DST for the award of a PURSE Fellowship. A.T. and F.G. also acknowledge Fondo Nacional de Desarrollo Científico y Tecnológico (FONDECYT-CONICYT (No, 3180511) Chile, for financial support.

\section{Acknowledgment}

We thank DST, New Delhi for providing the NMR facility for the Department of Organic Chemistry, University of Madras, Chennai, India under the DST-FIST Scheme.

\section{Supporting Information}

Supporting information for this article is available online at https://doi.org/10.1055/s-0039-1690333.

\section{References}

(1) (a) Albelda, M. T.; Frias, J. C.; Garcia-España, E.; Schneider, H.-J. Chem. Soc. Rev. 2012, 41, 3859. (b) Zhou, J.; Yu, G.; Huang, F. Chem. Soc. Rev. 2017, 46, 7021. (c) Lehn, J. M. Supramolecular chemistry: Concepts and Perspectives; VCH: Weinheim, 1995.

(2) (a) Salazar-Medina, A. J.; Sugich-Miranda, R.; Teran-Cabanillas, E.; Hernández, J.; González-Aguilar, G. A.; Rudiño-Piñera, E.; Sotelo-Mundo, R. R.; Velázquez-Contreras, E. F. Molecules 2013, 18, 1762. (b) Liu, Z.; Nalluri, S. K. M.; Stoddart, J. F. Chem. Soc. Rev. 2017, 46, 2459. (c) Ren, C.; Maurizot, V.; Zhao, H.; Shen, J.; Zhou, F.; Ong, W. Q.; Du, Z.; Zhang, K.; Su, H.; Zeng, H. J. Am. Chem. Soc. 2011, 133, 13930. (d) Zhang, D.-W.; Zhao, X.; Li, Z.-T. Acc. Chem. Res. 2014, 47, 1961.

(3) (a) Pattabiraman, V. R.; Bode, J. W. Nature 2011, 480, 471. (b) Anandhan, R.; Kannan, A.; Rajakumar, P. Synth. Commun. 2017, 47, 671 .

(4) (a) Hunter, C. A.; Purvis, D. H. Angew. Chem. Int. Ed. Engl. 1992, 31, 792. (b) Vandromme, L.; Monchaud, D.; Teulade-Fichou, M.P. Synlett 2006, 3423. 
(5) (a) Chang, S. K.; Van Engen, D.; Fan, E.; Hamilton, A. D. J. Am. Chem. Soc. 1991, 113, 7640. (b) Keaveney, C. M.; Leigh, D. A. Angew. Chem. Int. Ed. 2004, 43, 1222. (c) Abdelraheem, E. M. M.; Khaksar, S.; Dömling, A. Synthesis 2018, 50, 1027.

(6) (a) Andavan, G. S. B.; Lemmens-Gruber, R. Mar. Drugs 2010, 8, 810. (b) Jhaumeer-Laulloo, B. S.; Witvrouw, M. Indian J. Chem. 2000, 39, 842. (c) Jhaumeer-Laulloo, B. S. Asian J. Chem. 2000, $12,775$.

(7) Joo, S. H. Biomol. Ther. 2012, 20, 19.

(8) (a) Aghatabay, N. M.; Baş, A.; Kircali, A.; Şen, G.; Yazicioğlu, M. B.; Gücin, F.; Dülger, B. Eur. J. Med. Chem. 2009, 44, 4681. (b) Boojar, M. M.; Shockravi, A. Bioorg. Med. Chem. 2007, 15, 3437.

(9) Ngu-Schwemlein, M.; Gilbert, W.; Askew, K.; Schwemlein, S. Bioorg. Med. Chem. 2008, 16, 5778.

(10) (a) Delsuc, N.; Godde, F.; Kauffmann, B.; Léger, J.-M.; Huc, I. J. Am. Chem. Soc. 2007, 129, 11348. (b) Wei, X.; Zhang, G.; Shen, Y.; Zhong, Y.; Liu, R.; Yang, N.; Al-Mkhaizim, F. Y.; Kline, M. A.; He, L.; Li, M.; Lu, Z.-L.; Shao, Z.; Gong, B. J. Am. Chem. Soc. 2016, 8, 2749. (c) Fedorov, Y.; Fedorova, O.; Peregudov, A.; Kalmykov, S.; Egorova, B.; Arkhipov, D.; Zubenko, A.; Oshchepkov, M. J. Phys. Org. Chem. 2016, 29, 244. (d) Mattia, E.; Otto, S. Nat. Nanotechnol. 2015, 10, 111. (e) Ema, T.; Okuda, K.; Watanabe, S.; Yamasaki, T.; Minami, T.; Esipenko, N. A.; Anzenbacher, P. Jr. Org. Lett. 2014, 16, 1302. (f) Abdelraheem, M. M. E.; Khaksar, S.; Dömling, A. Synlett 2018, 29, 1136.

(11) (a) Du, P.; Jiang, X.-K.; Li, Z.-T. Tetrahedron Lett. 2009, 50, 316. (b) Zhu, Y.-Y.; Li, C.; Li, G.-Y.; Jiang, X.-K.; Li, Z.-T. J. Org. Chem. 2008, 73, 1745.

(12) El-Boraey, H. A.; El-Gammal, O. A. Spectrochim. Acta, Part A 2015, 138, 553.

(13) Cholewiak, A.; Stepniak, P.; Jurczak, J. Synthesis 2018, 50, 4555.

(14) Rajakumar, P.; Rasheed, A. M. A. Tetrahedron 2005, 61, 5351.

(15) (a) Rajakumar, P.; Padmanabhan, R. Tetrahedron 2011, 67, 9669. (b) Rajakumar, P.; Padmanabhan, R. Aust. J. Chem. 2012, 65, 186.

(16) (a) Rivera, D. G.; Vercillo, O. E.; Wessjohann, L. A. Synlett 2007, 308.

(17) (a) Raatikainen, K.; Beyeh, N. K.; Rissanen, K. Chem. Eur. J. 2010, 16, 14554. (b) Pang, T.; Yang, Q.; Gao, M.; Wang, M.; Wu, A. Synlett 2011, 3046. (c) Abbas, A. A. Synthesis 2004, 419. (d) Thirunarayanan, A.; Rajakumar, P. Synlett 2014, 25, 2127.

(18) (a) Kawase, T. Synlett 2007, 2609. (b) Cocq, K.; Barthes, C.; Rives, A.; Maraval, V.; Chauvin, R. Synlett 2019, 30, 30.

(19) (a) McDermott, B. P.; Campbell, A. D.; Ertan, A. Synlett 2008, 875. (b) Lazny, R.; Michalak, M. Synlett 2002, 1931. (c) Suchý, M.; Hudson, R. H. E. Synlett 2012, 893. (d) Gettys, K. E.; Ye, Z.; Dai, M. Synthesis 2017, 49, 2589.

(20) (a) Gulder, T.; Baran, S. P. Nat. Prod. Rep. 2012, 29, 899. (b) Huuskonen, J.; Rissanen, K. Liebigs Ann. 1995, 9, 1611. (c) Garda, Z.; Molnár, E.; Kálmán, F. K.; Botár, R.; Nagy, V.; Baranyai, Z.; Brücher, E.; Kovács, Z.; Tóth, I.; Tircsó, G. Front. Chem. 2018, 232. (d) Isidro-Llobet, A.; Murillo, T.; Bello, P.; Cilibrizzi, A.; Hodgkinson, J. T.; Galloway, W. R. J. D.; Bender, A.; Welch, M.; Spring, D. R. Proc. Natl. Acad. Sci. U.S.A. 2011, 108, 6793. (e) Swamy, S. J.; Veerapratap, B.; Nagaraju, D.; Suresh, K.; Someshwar, P. Tetrahedron 2003, 59, 10093.

(21) (a) Martí-Centelles, V.; Pandey, M. D.; Burguete, M. I.; Luis, S. V. Chem. Rev. 2015, 115, 8736. (b) Yu, X.; Zhang, J. Macrocyclic Polyamines: Synthesis and Applications in Organic Chemistry; Wiley-VCH: Weinheim, 2018, 237. (c) Bradshaw, J. S.; Krakowiak, K. E.; Izatt, R. M. The Chemistry of Heterocyclic Compounds, In Aza-Crown Macrocycles; John Wiley \& Sons: Weinheim, 2009, 17-896.
(22) (a) Rajakumar, P.; Rasheed, M. A.; Balu, P. M.; Murugesan, K. Bioorg. Med. Chem. 2006, 14, 7458. (b) Rajakumar, P.; Sekar, K.; Shanmugaiah, V.; Mathivanan, N. Eur. J. Med. Chem. 2009, 44, 3040.

(23) Viswanathan, V.; Thirunarayanan, A.; Rajakumar, P.; Velmurugan, D. Acta Crystallogr., Sect. E: Struct. Rep. Online 2014, 70, 0865.

(24) Synthesis of Precyclophane Amides; General Procedure A: A solution of the diacid chloride $(3.0 \mathrm{~g}, 1.48 \mathrm{mmol})$ in anhydrous dichloromethane $(100 \mathrm{~mL})$ and a solution of the amine $(4.82 \mathrm{~g}$, $2.96 \mathrm{mmol})$ and triethylamine $(1.65 \mathrm{~g}, 1.63 \mathrm{mmol})$ in anhydrous dichloromethane $(100 \mathrm{~mL})$ were simultaneously added dropwise with stirring to dichloromethane $(500 \mathrm{~mL})$ over $6 \mathrm{~h}$. After the addition was complete, the reaction mixture was stirred for another $6 \mathrm{~h}$. The solvent was removed under reduced pressure and the residue obtained was then dissolved in dichloromethane $(300 \mathrm{~mL})$, washed with water $(2 \times 100 \mathrm{~mL})$ to remove triethylamine hydrochloride and then dried over anhydrous $\mathrm{Na}_{2} \mathrm{SO}_{4}$. Filtration and removal of the dichloromethane gave the crude precyclophane, which was purified by column chromatography $\left(\mathrm{SiO}_{2}\right)$ using $\mathrm{CHCl}_{3} / \mathrm{MeOH}$ (97:3) as eluent.

Synthesis of Piperazinophanes/Cyclophane Amides by Mannich Reaction; General Procedure B: ${ }^{23}$ A mixture of precyclophane diyne $(0.2 \mathrm{~g}, 3.98 \mathrm{mmol})$, piperazine $(0.04 \mathrm{~g}, 3.98$ $\mathrm{mmol})$, and formaldehyde $(0.02 \mathrm{~g}, 7.96 \mathrm{mmol}$, from $37-41 \% \mathrm{aq}$. formaldehyde) and $\mathrm{CuCl}(0.04 \mathrm{~g}, 3.98 \mathrm{mmol})$ in dioxane $(30 \mathrm{~mL})$ was heated to reflux for $2 \mathrm{~h}$ under nitrogen. After the reaction was complete, the solvent was removed under reduced pressure, the residue was extracted with $\mathrm{CHCl}_{3}(3 \times 100 \mathrm{~mL})$, washed with water $(2 \times 100 \mathrm{~mL})$, brine $(150 \mathrm{~mL})$ and dried over anhydrous $\mathrm{Na}_{2} \mathrm{SO}_{4}$. The solvent was removed and the crude product was purified by column chromatography on silica gel using $\mathrm{CHCl}_{3} / \mathrm{MeOH}$ (24:1) as eluent.

$S$-Propargyloxy-2-aminothiophenol 19: The $S$-propargyloxy2-aminothiophenol (19) was prepared and obtained as darkbrown liquid, which was reported earlier from our laboratory. ${ }^{3 \mathrm{~b}}$ Preparation of Diacid Chlorides: The diacid chlorides 20-25 were prepared from the corresponding diacids, as reported earlier by our group. ${ }^{22}$

\section{Representative Analytical Data}

$N^{1}, N^{3}$-Bis(2-(prop-2ynylthio)phenyl)isophthalamide (14): By following General Procedure A, the precyclophane amide diyne $\mathbf{1 4}$ was obtained as a brown solid from diacid chloride $\mathbf{2 1}$ ( $3.0 \mathrm{~g}$, $1.48 \mathrm{mmol}$ ) and $S$-propargyloxy-2-aminothiophenol 19 (4.84 g, $2.97 \mathrm{mmol})$. Yield: $4.38 \mathrm{~g}(65 \%) ; \mathrm{mp} 120{ }^{\circ} \mathrm{C} .{ }^{1} \mathrm{H}$ NMR $(300 \mathrm{MHz}$, $\left.\mathrm{CDCl}_{3}\right): \delta=2.21(\mathrm{t}, J=2.4 \mathrm{~Hz}, 2 \mathrm{H}), 3.50(\mathrm{~d}, J=2.7 \mathrm{~Hz}, 4 \mathrm{H}), 7.16$ $(\mathrm{t}, J=7.5 \mathrm{~Hz}, 2 \mathrm{H}), 7.48(\mathrm{t}, J=8.1 \mathrm{~Hz}, 2 \mathrm{H}), 7.69(\mathrm{t}, J=7.8 \mathrm{~Hz}, 2 \mathrm{H})$, 8.20 (d, J = 6.6 Hz, $2 \mathrm{H}), 8.60$ (s, $2 \mathrm{H}), 8.60(\mathrm{~s}, 2 \mathrm{H}), 8.62(\mathrm{~s}, 2 \mathrm{H})$, $9.60(\mathrm{~s}, 2 \mathrm{H}) .{ }^{13} \mathrm{C}$ NMR $\left(75 \mathrm{MHz}, \mathrm{CDCl}_{3}\right): \delta=25.3,72.8,79.5$, $120.6,122.0,124.7,125.9,129.6,130.7,131.0,135.6,136.5$, 140.3, 164.2. MS (EI-TOF): $m / z=456\left[\mathrm{M}^{+}\right]$. Anal. Calcd for $\mathrm{C}_{26} \mathrm{H}_{20} \mathrm{~N}_{2} \mathrm{O}_{2} \mathrm{~S}_{2}$ : C, 68.33; H, 4.45; N, 6.20 .

5-Hydroxy- $N^{\mathbf{1}}, N^{3}$-bis(2-(prop-2-ynylthio)phenyl)isophthal Amide (17): By following General Procedure A, the precyclophane amide diyne $\mathbf{1 7}$ was obtained as a white solid from the diacid chloride 24 (3.0 g, $1.38 \mathrm{mmol}$ ) and $S$-propargyloxy-2aminothiophenol 19 (4.48 g, $2.8 \mathrm{mmol}$ ). Yield: $4.34 \mathrm{~g}(67 \%)$; mp $152{ }^{\circ} \mathrm{C} .{ }^{1} \mathrm{H}$ NMR $\left(300 \mathrm{MHz}, \mathrm{CDCl}_{3}\right): \delta=2.58(\mathrm{~s}, 2 \mathrm{H}), 3.52(\mathrm{~s}, 4 \mathrm{H})$, 7.16 (s, $2 \mathrm{H}), 7.43$ (s, $2 \mathrm{H}), 7.64(\mathrm{~s}, 4 \mathrm{H}), 7.99(\mathrm{~s}, 1 \mathrm{H}), 8.39$ (s, $2 \mathrm{H}), 9.55(\mathrm{~s}, 2 \mathrm{H}), 9.89(\mathrm{~s}, 1 \mathrm{H}) .{ }^{13} \mathrm{C}$ NMR $\left(75 \mathrm{MHz}, \mathrm{CDCl}_{3}\right): \delta=$ 24.2, 72.5, 79.1, 116.1, 117.5, 120.9, 122.8, 124.4, 129.9, 135.2, 136.2, 139.4, 158.0, 164.1. MS (EI-TOF): $m / z=472\left[\mathrm{M}^{+}\right]$. Anal. Calcd for $\mathrm{C}_{26} \mathrm{H}_{20} \mathrm{~N}_{2} \mathrm{O}_{3} \mathrm{~S}_{2}$ : C, 65.97; $\mathrm{H}, 4.20 ; \mathrm{N}, 6.02$. 
Cyclophane Amide 1: The cyclophane amide 1 was afforded as a white solid from the precyclophane amide diyne $13(0.4 \mathrm{~g}$, $0.88 \mathrm{mmol})$, piperazine $(0.08 \mathrm{~g}, 0.88 \mathrm{mmol})$, formaldehyde $(0.05$ g, $1.76 \mathrm{mmol}$, from 37-41\% aq. formaldehyde) and $\mathrm{CuCl}(0.09 \mathrm{~g}$, $0.88 \mathrm{mmol}$ ). Yield: $0.15 \mathrm{~g}(31 \%) ; \mathrm{mp} 186{ }^{\circ} \mathrm{C} .{ }^{1} \mathrm{H}$ NMR $(300 \mathrm{MHz}$, $\left.\mathrm{CDCl}_{3}\right): \delta=2.56(\mathrm{~s}, 8 \mathrm{H}), 3.04(\mathrm{~s}, 4 \mathrm{H}), 3.56(\mathrm{~s} ., 4 \mathrm{H}), 7.14(\mathrm{t}, J=7.5$ $\mathrm{Hz}, 2 \mathrm{H}), 7.45(\mathrm{t}, J=7.8 \mathrm{~Hz}, 2 \mathrm{H}), 7.64(\mathrm{t}, J=7.5 \mathrm{~Hz}, 2 \mathrm{H}), 7.68$ (s, $4 \mathrm{H}), 8.12$ (d, $J=8.1 \mathrm{~Hz}, 2 \mathrm{H}), 9.69(\mathrm{~s}, 2 \mathrm{H}) .{ }^{13} \mathrm{C}$ NMR $(75 \mathrm{MHz}$, $\left.\mathrm{CDCl}_{3}\right): \delta=25.6,46.8,51.4,79.2,80.2,119.1,120.3,122.8,124.6$, 131.5, 136.3, 137.1, 140.3, 164.3. MS (EI-TOF): $m / z=566\left[\mathrm{M}^{+}\right]$. Anal. Calcd for $\mathrm{C}_{32} \mathrm{H}_{30} \mathrm{~N}_{4} \mathrm{O}_{2} \mathrm{~S}_{2}$ : C, 67.89; H, 5.26; N, 9.97.

Cyclophane Amide 4: General Procedure B was followed for the synthesis of cyclophane amide $\mathbf{4}$ as a white solid from the precyclophane amide diyne $\mathbf{1 6}(0.4 \mathrm{~g}, 0.88 \mathrm{mmol})$, piperazine ( 0.08 $\mathrm{g}, 0.88 \mathrm{mmol})$, formaldehyde $(0.05 \mathrm{~g}, 1.76 \mathrm{mmol}$, from $37-41 \%$ aq. formaldehyde) and $\mathrm{CuCl}(0.09 \mathrm{~g}, 0.88 \mathrm{mmol})$. Yield: $0.18 \mathrm{~g}$ (36\%); $\mathrm{mp} 120{ }^{\circ} \mathrm{C} .{ }^{1} \mathrm{H} \mathrm{NMR}\left(300 \mathrm{MHz}, \mathrm{CDCl}_{3}\right): \delta=2.22(\mathrm{~s}, 8 \mathrm{H})$, $3.11(\mathrm{~s}, 4 \mathrm{H}), 3.66(\mathrm{~s}, 4 \mathrm{H}), 7.29$ (d, J = 7.8 Hz, $2 \mathrm{H}), 7.38(\mathrm{t}, J=7.8$ $\mathrm{Hz}, 2 \mathrm{H}), 7.63$ (d, J = 7.8 Hz, $2 \mathrm{H}), 8.01(\mathrm{~d}, J=6.3 \mathrm{~Hz}, 2 \mathrm{H}), 8.12$ (t, $J=7.8 \mathrm{~Hz}, 1 \mathrm{H}), 8.39$ (d, $J=7.8 \mathrm{~Hz}, 2 \mathrm{H}), 10.76(\mathrm{~s}, 2 \mathrm{H}) .{ }^{13} \mathrm{C}$ NMR $\left(75 \mathrm{MHz}, \mathrm{CDCl}_{3}\right.$ ): $\delta=22.7,46.8,50.5,78.2,82.0,123.4,123.8$, 125.5, 126.4, 129.5, 130.9, 138.6, 139.3, 150.5, 163.1. MS: $m / z=$ $567\left[\mathrm{M}^{+}\right]$. Anal. Calcd for $\mathrm{C}_{31} \mathrm{H}_{29} \mathrm{~N}_{5} \mathrm{O}_{2} \mathrm{~S}_{2}$ : C, 65.49; H, 5.26; N, 12.37 . 